KA Azizi Noviansyah dan Dimas Agung Ibrahim, Pelaksanaan Prinsip Kepesertaan Bersifat Wajib Pada Sistem Jaminan Sosial Ketenagakerjaan, Halaman 203-222

\title{
PELAKSANAAN PRINSIP KEPESERTAAN BERSIFAT WAJIB PADA SISTEM JAMINAN SOSIAL KETENAGAKERJAAN
}

\author{
KA. Azizi Noviansyah ${ }^{1}$ \\ dan Dimas Agung Ibrahim² \\ ${ }^{1}$ Kepala UPT Perpustakaan Politeknik Akamigas Palembang \\ E-mail: iantato25@gmail.com \\ ${ }^{2}$ Bidang Audit BPJS Ketenagakerjaan Kantor Cabang Palembang \\ E-mail: dimas.ibrahim@bpjsketenagakerjaan.go.id
}

\begin{abstract}
The result of this research is the implementation of the Mandatory Membership Principle On Labor Social Security System are through Evaluation of Membership, Membership Additions Growth Analysis, Analysis of Active Participation, support from the Human Resources and through BPJS Ketenagakerjaan Branch Office Palembang Operations and Services programs. The limiting factors of the Implementation are : the existence of other private insurance agencies; the lack of public and companies awareness; administrative sanctions on employers; limited informal sector workers membership growth; and the differences in the calculation of the value of contributions to be paid by the company. Supporting factors are: efforts of the government to rise Law No. 24 of 2011 concerning the Social Security Administrator Agency (BPJS); firmness of the law enforcers; good coordination among agencies from central to local levels; socialization by cooperating with the mass media; service and the ease of access registration system through E-Channel.
\end{abstract}

Keywords : Mandatory Membership Principles; Employment

\begin{abstract}
Abstrak
Hasil penelitian ini adalah pelaksanaan pada prinsip kepesertaan bersifat wajib pada Sistem Jaminan Sosial Ketenagakerjaan antara lain melalui Evaluasi Kepesertaan, Analisa Pertumbuhan Penambahan Kepesertaan, Analisa Kepesertaan Aktif, dukungan Sumber Daya Manusa dan program-program Operasional dan Pelayanan BPJS Ketenagakerjaan Kacab Palembang. Faktor Penghambat Pelaksanaan Prinsip Kepesertaan Bersifat Wajib pada Sistem Jaminan Sosial Ketenagakerjaan adalah : keberadaan lembaga asuransi swasta lain; lemahnya kesadaran masyarakat dan perusahaan; sanksi administratif kepada pemberi kerja; terbatasnya pertumbuhan kepesertaan pekerja sektor informal; dan perbedaan perhitungan nilai iuran yang harus dibayar perusahaan. Faktor-faktor pendukungnya adalah : upaya pemerintah menerbitkan Undang-Undang Nomor 24 Tahun 2011 tentang Badan Penyelenggaran Jaminan Sosial (BPJS); ketegasan penegak hukum; koordinasi yang baik antar lembaga dari tingkat pusat hingga daerah; sosialisasi dengan menggandeng kerjasama dengan media massa; sistem pelayanan dan kemudahan akses pendaftaran melalui E-Channel.
\end{abstract}

Kata Kunci : Prinsip Kepesertaan Wajib; Ketenagakerjaan

\section{PENDAHULUAN}

Menurut ketentuan Pasal 17 UU Jamsostek, pengusaha dan pekerja wajib ikut serta dalam program jaminan sosial tenaga kerja. Berdasarkan ketentuan ini, pihak yang menjadi peserta ada 2 (dua) golongan, yaitu pengusaha dan pekerja. Yang termasuk golongan pekerja adalah setiap orangyang mampu melakukan pekerjaan, baik di dalam maupun di luar 
KA Azizi Noviansyah dan Dimas Agung Ibrahim, Pelaksanaan Prinsip Kepesertaan Bersifat Wajib Pada Sistem Jaminan Sosial Ketenagakerjaan, Halaman 203-222

hubungan kerja guna menghasilkan jasa atau barang untuk memenuhi kebutuhan masyarakat. $^{1}$

Pemerintah selalu berupaya untuk memberikan fasilitas yang terbaik untuk seluruh rakyatnya, agar seluruh rakyat Indonesia dapat merasakan perlindungan hukum yang diberikan oleh Negara ini khususnya rakyat Indonesia. Pemerintah kita tidak hanya berhenti dengan satu peraturan saja dalam mensejahterakan rakyatnya, mereka selalu mencari cara bagaimana agar seluruh lapisan masyarakat di Indonesia dapat merasakan kesejahteraan dan ketenteraman dalam bekerja tidak perlu khawatir apabila mengalami keadaan-keadaan yang sulit dalam melindungi dirinya dan keluarganya dari risiko yang mungkin saja akan terjadi. Salah satu bukti bahwa pemerintah kita terus berupaya menciptakan peraturan yang lebih bermutu dan bisa dirasakan oleh seluruh masyarakat Indonesia yaitu pemerintah kita melahirkan Undang-Undang Badan Penyelenggaraan Jaminan Sosial (BPJS) dan merupakan transformasi dari empat Badan Usaha Milik Negara (BUMN) untuk mempercepat terselenggaranya sistem jaminan sosial nasional bagi

1 Muhammad Abdulkadir, Hukum Asuransi Indonesia, Bandung: PT. Citra Aditya Bakti, 2006, hlm. 223-224. rakyat Indonesia sebagaimana amanat dari Pasal 5 ayat (1) dan Pasal 52 Undang-Undang Nomor 40 Tahum 2004 tentang Sistem Jaminan Sosial Nasionalyang selanjutnya disebut UU SJSN. Dimana dalam undang-undang tersebut dibentuk 2 (dua) badan penyelenggara yaitu BPJS Kesehatan dan BPJS Ketenagakerjaan. BPJS Kesehatan menggantikan PT. Askes dan BPJS Ketenagakerjaan menggantikan PT. Jamsostek, setelah diberlakukannya BPJS Kesehatan dan BPJS Ketenagakerjaan maka PT. Askes dan PT. Jamsostek sudah tidak diberlakukan lagi. $^{2}$

Dalam perjalanannya yang panjang, jaminan sosial telah berlabuh dengan utuh pada UU SJSN dan implementasinya dengan keluarnya Undang-Undang Nomor 24 Tahun 2011 tentang Badan Penyelenggara Jaminan Sosial yang selanjutnya disebut UU BPJS, memberikan kepastian bahwa bangsa Indonesia telah menetapkan pilihan sistem jaminan sosial yang benar-benar menerapkan prinsip-prinsip jaminan sosial yang bersifat universal dan telah banyak diterapkan di negaranegara maju dan negara

${ }^{2}$ Republik Indonesia, Undang-Undang Republik Indonesia Nomor 24 Tahun 2011 Tentang Badan Penyelenggara Jaminan Sosial (BPJS), hlm. IV. 
KA Azizi Noviansyah dan Dimas Agung Ibrahim, Pelaksanaan Prinsip Kepesertaan Bersifat Wajib Pada Sistem Jaminan Sosial Ketenagakerjaan, Halaman 203-222

berkembang. Kehadiran BPJS Kesehatan dan BPJS Ketenagakerjaan, yang telah dinanti-nanti cukup lama dengan berbagai dinamika masyarakat yang tinggi dalam proses penerbitan dan menjadi batu loncatan mencapai cita-cita kesejahteraan (welfare state). Pasal 13 ayat 1 UU SJSN, serta Pasal 15 ayat 1 UU BPJS menyatakan bahwa "Pemberi kerja secara bertahap wajib mendaftarkan dirinya dan pekerjanya sebagai peserta kepada Badan Penyelenggara Jaminan Sosial, sesuai dengan program jaminan sosial yang diikuti.

Agar kepesertaan bersifat wajib dipatuhi oleh segenap pengusaha dan pekerja, maka salah satunya ditetapkan pada Pasal 54 UU BPJS, yaitu memberikan sanksi pidana yang tujuannya untuk mendidik yang bersangkutan dalam memenuhi kewajibannya. Sanksi tersebut merupakan upaya terakhir,setelah upaya-upaya lain dilakukan dalam rangka memegahkan ketentuan-ketentuan yang berlaku.

Tentunya penerapan prinsip kepesertaan bersifat wajib ini memiliki banyak manfaat baik bagi pengusaha dan pekerja. Tetapi pada kenyataannya prinsip ini memiliki kendala-kendala dalam berbagai aspek dan bagi pengusaha dan pekerja, antara lain adalah dugaan terhadap monopoli pemerintah dalam penyelenggaraan jasa layanan jaminan sosial yang berimbas langsung bagi penyedia jasa layanan kesehatan lainnya (perusahaan asuransi lainnya) ${ }^{3}$ dan sebagainya, yang tentunya dalam pelaksanannya dan diperlukan adanya solusi terhadap kendala yang timbul tersebut.

Permasalahan yang dibahas dalam penelitian ini dapat dirumuskan sebagai berikut : Pertama, bagaimana penerapan prinsip kepesertaan bersiifat wajib pada sistem jaminan sosial ketenagakerjaan. Kedua, faktor penghambat dan pendukung penerapan prinsip kepesertaan bersifat wajib.

Jenis penelitian ini adalah penelitian hukum normatif dengan pendekatan perundang-undangan (statute approach), pendekatan perbandingan (comparative approach), pendekatan kasus (case approach), dan pendekatan kemasyarakatan (social approach). Lokasi penelitian adalah BPJS Ketenagakerjaan Kanwil Sumbagsel, Jalan Basuki Rahmat Nomor 1303 A-B Palembang, 30126 dan BPJS Ketenagakerjaan Cabang Palembang,

\footnotetext{
${ }^{3}$ Kepesertaan Wajib : BPJS Bukan Domain Swasta, http:// www.hukumonline.com, diakses Tanggal 31 Januari 2019.
} 
KA Azizi Noviansyah dan Dimas Agung Ibrahim, Pelaksanaan Prinsip Kepesertaan Bersifat Wajib Pada Sistem Jaminan Sosial Ketenagakerjaan, Halaman 203-222

Jalan Jendral Sudirman Nomor 131 Palembang, 30126. Jenis dan Sumber data dari penelitian ini diperoleh dari data primer, sekunder dan data tertier. Teknik pengumpulan data menggunakan dua cara pengumpulan data, yaitu Studi Lapangan (field research) dan Studi Kepustakaan (library research). Data yang diproses akan diolah dan diproses dengan cara melakukan pemeriksaan data (editing) penandaan data (coding) rekonstruksi hukum data (reconstructing) dan sistematisasi data (systematizing). Analisis data menggunakan analisis kualitatif dengan teknik penarikan kesimpulan secara induktif.

\section{PEMBAHASAN}

\section{A. Penerapan Prinsip Kepesertaan} bersifat Wajib pada Sistem Jaminan Sosial Ketenagakerjaan

\section{Filosofis Pelaksanaan Jaminan Sosial Ketenagakerjaan}

Secara rasional, para pelaku bisnis akan mempertimbangkan untuk mengurangi risiko yang dihadapi. Pada tingkat kehidupan keluarga atau rumah tangga, asuransi juga dibutuhkan untuk mengurangi permasalahan ekonomi yang akan dihadapi apabila ada salah satu anggota keluarga yang menghadapi risiko cacat atau meninggal dunia. ${ }^{4}$ Asuransi merupakan salah satu dari buah peradaban manusia dan merupakan suatu hasil evaluasi kebutuhan manusia yang sangat hakiki ialah kebutuhan akan rasa aman dan terlindung, terhadap kemungkinan menderita kerugian. Di zaman sekarang asuransi memegang peranan penting dalam memberikan kepastian proteksi bagi manusia. Asuransi dapat memberikan proteksi terhadap kesehatan, pendidikan, hari tua, harta benda maupun kematian yang ditujukan kepada masyarakat luas. Asuransi merupakan buah pikirian dan akal budi manusia untuk mencapai suatu keadaan yang dapat memenuhi kebutuhannya, terutama sekali untuk kebutuhan-kebutuhannya yang hakiki sifatnya. $^{5}$

Definisi asuransi dapat ditemukan pada Kitab Undang-Undang Hukum Dagang Pasal 246 yang menyatakan bahwa Asuransi atau pertanggungan adalah suatu perjanjian dengan mana seseorang penanggung mengikatkan diri kepada seseorang tertanggung, dengan menerima suatu premi untuk memberikan

4 Abdulkadir Muhammad, 2006, Hukum Asuransi Indonesia, Bandung: PT. Citra Aditya Bakti, hlm. 5.

5 Sri Rejeki Hartono, 2001, Hukum Asuransi dan Perusahaan Asuransi, Jakarta: Sinar Grafika, hlm. 30. 
KA Azizi Noviansyah dan Dimas Agung Ibrahim, Pelaksanaan Prinsip Kepesertaan Bersifat Wajib Pada Sistem Jaminan Sosial Ketenagakerjaan, Halaman 203-222

penggantian kepadanya karena suatu kerugian, kerusakan, atau kehilangan keuntungan yang diharapkan, yang mungkin terjadi karena suatu peristiwa tak tentu.

Selain itu secara khusus Badan Penyelenggara Jaminan Sosial (BPJS) menyelenggarakan Sistem Jaminan Sosial Nasional (SJSN), menurut Pasal 2 Undang-Undang BPJS berdasarkan asas kemanusiaan yang terkait dengan penghargaan terhadap martabat manusia. Manfaat yaitu asas yang bersifat operasional yang menggambarkan pengelolaan yang efisien dan efektif, sedangkan asas yang bersifat idiil yaitu keadilan sosial bagi seluruh rakyat Indonesia. Sebagai badan Hukum Publik pembentukan Badan Penyelenggara Jaminan Sosial berdasarkan Undang-Undang BPJS. Fungsi, tugas, wewenang, hak dan kewajibannya juga diatur dalam Undang-Undang BPJS. Undang-Undang BPJS menentukan bahwa BPJS bertanggung jawab kepada Presiden. Hal ini berbeda dengan Direksi PT (Persero) yang bertanggung jawab kepada Rapat Umum Pemegang Saham (RUPS). Seperti diketahui bersama bahwa "Jaminan sosial merupakan hak setiap warga Negara yang dilindungi oleh Undang-Undang”. Namun kenyataannya

belum seluruh warga Negara mendapatkan akses Jaminan Sosial Nasional tersebut. Dalam Undang-Undang Dasar 1945, pada alinea kelima, dinyatakan bahwa keadilan sosial diperuntukkan bagi seluruh rakyat Indonesia dan Sistem jaminan sosial tercantum dalam Pasal 34 UUD Amandemen keempat Tahun 2002.

Berdasarkan

filosofis di atas justru menyiratkan bahwa kedudukan Jaminan Sosial merupakan keinginan seluruh rakyat Indonesia khususnya masyarakat pekerja, ${ }^{6}$ bersifat urgent dan harus diperoleh serta diikutsertakan bagi setiap warga Negara Indonesia yang dimana pada dasarnya Jaminan Sosial adalah dalam rangka menjamin

${ }^{6}$ Keinginan masyarakat pekerja, berkehidupan sesuai dengan konsep negara hukum kesejahteraan Pancasila menurut UUD 1945, tentu saja mengandung jiwa dan semangat Pancasila, yang oleh Hadjon disebutnya "jiwa dan isi negara hukum Pancasila", yaitu negara menghendaki keserasian hubungan antara pemerintah dan rakyat berdasarkan asas kerukunan; terjalinnya hubungan fungsional yang proporsional antara kekuasaan-kekuasaan negara; penyelesaian sengketa secara musyawarah, sedangkan peradilan merupakan sarana terakhir; menekankan hak asasi manusia yang seimbang dengan kewajiban asasi manusia. Lihat: Muhammad Syaifuddin, "Nasionalisasi Perusahaan Modalasing Ide Normatif Pengaturan Hukumnya Dalam UU NO.25 Tahun 2007 Dan Relevansinya Dengan Konsep Negara Hukum Kesejahteraan Pancasila Dalam UUD 1945",Jur-nal Simbur Cahaya,Vol. XVII No.47 Januari 2012, Palembang: FH UNSRI, hlm. 2835. 
KA Azizi Noviansyah dan Dimas Agung Ibrahim, Pelaksanaan Prinsip Kepesertaan Bersifat Wajib Pada Sistem Jaminan Sosial Ketenagakerjaan, Halaman 203-222

perlindungan sosial dan

kesejahteraan serta memenuhi kebutuhan dasar hidupnya yang layak.

Dengan berubahnya PT Jamsostek menjadi BPJS Ketenagakerjaan terdapat perbedaan terhadap jenis program jaminan sosial dimana pada masa Jamsostek berdasarkan Undang Undang Nomor 3 Tahun 1992 dikenal program jaminan sosial yang meliputi Jaminan Kecelakaan Kerja, Jaminan Kematian, Jaminan Hari Tua, Jaminan Pemeliharaan Kesehatan sedangkan didalam Undang-Undang BPJS program jaminan didalam Pasal 18 yang meliputi Jaminan Kesehatan, Jaminan Kecelakaan Kerja, Jaminan Hari Tua, Jaminan Pensiun, dan Jaminan Kematian. Dengan beroperasinya penuh BPJS Ketenagakerjaan itu, maka per 1 Juli 2015 seluruh pekerja wajib menjadi peserta jaminan sosial ketenagakerjaan. ${ }^{7}$

\section{Evaluasi Penerapan Prinsip}

\section{Kepesertaan Bersifat Wajib}

Evaluasi penerapan prinsip kepesertaan bersifat wajib pada penyelenggaraan sistem jaminan sosial meliputi target dan realisasi kepesertaan dalam program-program BPJS

\footnotetext{
${ }^{7}$ Presiden Jokowi : Setiap Pekerja Wajib Jadi Peserta BPJS Ketenagakerjaan, http://setkab.go.id/, diakses Tqanggal 17 Juni 2019.
}

Ketenagakerjaan pada propinsi-propinsi di Sumbagsel Tahun 2016 yang meliputi penambahan perusahaan, penambahan TK PU (Tenaga Kerja Penerima Upah, Penambahan TK BPU (Tenaga Kerja Bukan Penerima Upah), Perusahaan Aktif, dan Tenaga Kerja Aktif. Hal ini bertujuan untuk mengetahui sejauh mana peraturan perundang-undangan ini dapat diterapkan oleh subyek hukum yang ada didalamnya.

\section{Analisa Penambahan Kepesertaan}

Penyelenggaraan jaminan sosial ketenagakerjaan diarahkan untuk sebesar-besarnya bagi kemakmuran dan kesejahteraan masyarakat pekerja. Oleh karena itu peraturan tentang ketenagakerjaan harus dapat menjamin kepastian hukum, nilai keadilan, asas kemanfaatan, ketertiban, perlindungan dan penegakan hokum. Analisa penambahan kepesertaan dalam program BPJS Ketenagakerjaan harus dilakukan secara mendalam, sehingga penerapan prinsip kepesertaan bersifat wajib dapat diterapkan. Analisa penambahan kepesertaan BPJS Ketenagakerjaan dibagi menjadi penambahan kepesertaan penerima upah dan penambahan kepesertaan bukan penerima upah.

\section{Analisa Kepesertaan Aktif}


KA Azizi Noviansyah dan Dimas Agung Ibrahim, Pelaksanaan Prinsip Kepesertaan Bersifat Wajib Pada Sistem Jaminan Sosial Ketenagakerjaan, Halaman 203-222

Secara keseluruhan kepesertaan aktif peserta BPJS Ketenagakerjaan Kantor Wilayah Sumbagsel beserta jajaran sampai dengan September 2016 telah tercapai sebanyak 26.202 Perusahaan (95\%) dan 1.238.377 tenaga kerja (108\%). Untuk jumlah perusahaan aktif pada bulan ini mengalami penurunan sebesar 5\% dari 27.546 Perusahaan menjadi 26.202 Perusahaan sedangkan untuk jumlah tenaga kerja aktif mengalami kenaikan sebesar $2 \%$ dari 1.214.177 tenaga kerja menjadi 1.238.377 tenaga kerja.

\section{Operasional dan Pelayanan}

Semua hal yang berhubungan dengan pencapaian kinerja unit kerja selalu didukung oleh Sistem SDM yang baik. Kantor Cabang Palembang khususnya memiliki personil sebanyak 39 orang karyawan. Operasional dan pelayanan di era BPJS Ketenagakerjaan dilaksanakan melalui beberapa poin penting yaitu $:^{8}$

1) Anywhere, yaitu akses kepada pekerja dimanapun mereka berada;

2) Anyhow, yaitu akses kepada pekerja dengan media apapun;

\footnotetext{
${ }^{8}$ Materi Forum Group Discussion (FGD) BPJS Ketenagakerjaan Cabang Palembang 21 Juli 2016 di Hotel Aston Palembang.
}

3) Anytime, yaitu akses kepada pekrja kapan pun;

4) Zero fraud, yaitu keunggulan operasional dan pelayanan untuk memudahkan peserta menekan fraud. ${ }^{9}$

Implementasi Easynese Access atau kemudahan akses 10 antara lain dilaksanakan melalui beberapa kemudahan yaitu : ${ }^{11}$

1) Kantor Pelayanan yang terdiri atas 11 Kantor Wilayah, 121 Kantor Cabang, 53 Kantor Cabang Pembantu, serta 1102 outlet antara lain Bank Mandiri, Bank BNI 46, Bank BNI, Bank BRI, Bank Bukopin, dan Bank BJB;

2) Adanya mobil keliling yang memudahkan peserta mendapatkan informasi serta pelayanan BPJS Ketenagakerjaan; ${ }^{12}$

\footnotetext{
${ }^{9}$ Fraud ialah setiap tindakan ilegal yang ditandai dengan tipu daya, penyembunyian atau pelanggaran kepercayaan. Tindakan ini tidak tergantung pada penerapan ancaman kekerasan atau kekuatan fisik. Penipuan yang dilakukan oleh individu, dan organisasi untuk memperoleh uang, kekayaan atau jasa; untuk menghindari pembayaran atau kerugian jasa; atau untuk mengamankan keuntungan bisnis pribadi. Lihat: Tuanakotta, Theodorus M., Audit Berbasis ISA (International Standards on Auditing), Jakarta: Salemba Empat, 2013, hlm. 28.

10 Kemudahan akses atau Aksesibilitas adalah derajat kemudahan dicapai oleh orang, terhadap suatu objek, pelayanan ataupun lingkungan. Lihat : $\quad$ https://id.wikipedia.org/wiki/Aksesibilitas, diakses Tanggal 20 Juni 2019.

11 Materi FGD, Op.Cit.

12 Mobil keliling ini berfungsi membantu Kantor BPJS Ketenagakerjaan dalam melakukan
} 
KA Azizi Noviansyah dan Dimas Agung Ibrahim, Pelaksanaan Prinsip Kepesertaan Bersifat Wajib Pada Sistem Jaminan Sosial Ketenagakerjaan, Halaman 203-222

3) Mesin-mesin kios elektronik yang memudahkan peserta mendapatkan informasi dan pelayanan secara online $;^{13}$

4) Layanan SMS dan Website yang dapat diakses di bpjsketenagakerjaan.go. id

5) Pelayanan BPJS TK Mobile Google Store melalui Android;

6) Aliansi dengan Pemda melalui Desk Service di pemda Tingkat Kabupaten/Kota, serta aliansi Industri Retail seperti Indomaret dan Alfamart.

\section{Faktor-faktor Penghambat dan} Pendukung Penerapan Prinsip Kepesertaan Bersiifat Wajib Pada Sistem Jaminan Sosial

\section{Ketenagakerjaan}

\section{a. Faktor-faktor Penghambat}

perluasan kepesertaan, pengelolaan kepesertaan dan pelayanan jaminan kepada peserta/calon peserta BPJS Ketenagakerjaan. Mobil keliling ini berpindah-pindah dari suatu tempat ke tempat lainnyasesuai kebutuhan atau ada permintaan dari pihak lain. Minimal 2 karyawan akan ditugaskan untuk melaksanakan aktifitas di setiap unitnya. Lihat : Romie Erfianto, 2015, Dengan IT Kemudahan Akses Bisa Terwujud, Bridge (Jembatan Menuju Kesejahteraan Pekerja), Vol. 09 .

13 Peluncuran kios elektronik untuk menggaet peserta pekerja bukan penerima upah atau non formal. Kios elektronik ini menawarkan pendaftaraan kepesertaan secara mandiri khusus kepada pekerja bukan penerima. Untuk dapat mendaftarkan diri, calon peserta harus sudah memiliki elektronik kartu tanda penduduk atau nomor induk kependudukan dan berusia tidak lebih dari 65 tahun. Kios-kios ini disebar ke seluruh kantong-kantong pekerja bukan penerima upah seperti penjaga toko, tukang parkir, pedagang, dan lain sebagainya. Lihat: Ibid.

\section{1) Tumpang Tindih Hukum \\ Ketenagakerjaan}

Peraturan Pemerintah Nomor 60 tahun 2015 tentang penyelenggaraan program jaminan hari tua dan Peraturan Menteri Tenaga Kerja Nomor 19 Tahun 2015 tentang tata cara dan persyaratan pembayaran manfaat jaminan hari tua bertentangan dengan aturan diatasnya. Misalnya Undang-Undang Nomor 40 Tahun 2004 tentang Sistem Jaminan Sosial Nasional. Pasal 33 Undang-Undang tersebut menyebutkan, program JHT bisa dicairkan dengan tiga kondisi yaitu meninggal dunia, pensiun dan cacat total. Namun Permenaker Nomor 19 Tahun 2015 memperbolehkan pekerja yang mengalami pemutusan hubungan kerja mencairkan dana JHT.

Aturan lain yang bertentangan dengan aturan diatasnya yaitu Peraturan Pemerintah Nomor 70 Tahun 2015 tentang Program Kematian dan Kecelakan Kerja bagi Aparatur Sipil Negara. Aturan tersebut menyatakan, program kematian dan kecelakan kerja bagi aparatur sipil negara diselenggarakan oleh PT. Taspen. Hal ini justru bertentangan dengan Undang-Undang Nomor 24 Tahun 2011 
KA Azizi Noviansyah dan Dimas Agung Ibrahim, Pelaksanaan Prinsip Kepesertaan Bersifat Wajib Pada Sistem Jaminan Sosial Ketenagakerjaan, Halaman 203-222

tentang Badan Penyelenggara Jaminan Sosial Ketenagakerjaan.

\section{2) Kesadaran Hukum Pemberi Kerja dan Pekerja}

Kendala paling besar yang menghambat perkembangan BPJS Ketenagakerjaan di Kota Palembang adalah karena masih minimnya jumlah kepesertaan. Hal itu disebabkan karena belum adanya kesadaran masyarakat ataupun pihak pengusaha untuk mendaftarkan karyawanya menjadi anggota badan jaminan sosial tersebut.

\section{3) Sanksi Bagi Pemberi Kerja}

Hal yang menjadi kendala lain adalah adanya sanksi administratif kepada pemberi kerja apabila tidak mendaftarkan pekerjanya ke BPJS seperti diatur Pasal 17 ayat (1) dan (2) huruf c UU BPJS. Permasalahan berikutnya adalah bahwa penyelenggara negara tidak dikenai sanksi administratif bila tidak mendaftarkan bPJS bagi pekerja/pegawainya. Sanksi tidak mendapat pelayanan publik tertentu yang dikenai kepada Pemberi Kerja Selain Penyelenggara Negara pada Pasal 9 ayat (1) Peraturan Pemerintah Republik Indonesia Nomor 86 Tahun 2013 tentang Tata Cara Pengenaan Sanksi
Administratif Kepada Pemberi Kerja Selain Penyelenggara Negara dan Setiap Orang, Selain Pemberi Kerja, Pekerja, dan Penerima Bantuan Iuran Dalam Penyelenggaraan Jaminan Sosial (selanjutnya disebut PP No. 86 Tahun 2013).

Sanksi administratif bagi pemberi kerja selain penyelenggara dalam Pasal 17 UU BPJS ini dinilai diskriminatif. Sebab, ada pembedaan antara pemberi kerja bukan penyelenggara negara (swasta) dan pemberi kerja sebagai penyelenggara negara. Aturan ini mengasumsikan penyelenggara negara tidak pernah salah, sehingga diistimewakan perlakuannya. Kekhawatirannya adalah faktanya tidak demikian. Dalam Pasal 55 UU BPJS, disebutkan ancaman pidana selama 8 tahun dan denda satu miliar rupiah bagi pemberi kerja yang menunggak iuran. Ironinya, bagi pemberi kerja yang tidak melaksanakan kewajiban untuk mendaftarkan dirinya dan pekerjanya hanya akan mendapatkan sanksi administratif berupa tak mendapatkan layanan publik sesuai dengan pasal 17 UU BPJS dan PP No. 86 Tahun 2013. ${ }^{14}$

\footnotetext{
14 KPK Temukan Kelemahan Sistem BPJS Ketenagakerjaan,
} 
KA Azizi Noviansyah dan Dimas Agung Ibrahim, Pelaksanaan Prinsip Kepesertaan Bersifat Wajib Pada Sistem Jaminan Sosial Ketenagakerjaan, Halaman 203-222

\section{4) Penerapan Aturan Hukum Yang}

\section{Belum Merata}

Pertumbuhan kepesertaan pekerja sektor informal antara lain terkendala oleh pembayaran iuran dan tingkat kepatuhan bulanan, mengingat pekerja sektor informal merupakan para pekerja di skala $\mathrm{UMKM}^{15}$ dengan penghasilan yang terbatas. Sosialisasi serta edukasi oleh Pemda untuk mendorong perusahaan-perusahaan untuk mendaftarkan pekerjanya dalam program BPJS Ketenagakerjaan merupakan beberapa solusi penting mengatasi permasalahan ini.

\section{5) Pemahaman Aturan Yang Tidak Sama}

http://www.pikiran-rakyat.com, diakses Tanggal 10 Juni 2019.

15 Berdasarkan UU No. 20 Tahun 2008 Tentang UMKM, Usaha Mikro, Kecil, dan Menengah didefinisikan sebagai perusahaan milik perseorangan WNI dengan kekayaan bersih maksimum sepuluh milyar rupiah dan penjualan tahunan maksimum lima puluh milyar rupiah. Usaha Mikro Kecil Menengah (UMKM) adalah pelaku usaha yang dalam menjalankan usahanya memiliki jumlah penjualan sebesar < Rp 1.000.000.000 per tahun dan biasanya jumlah yang digunakan pun biasanya relatif sedikit. Adapun berbagai bidang usaha UMKM adalah seperti usaha rumah makan, usaha pembuatan makanan dan minuman ringan, kerajinan tangan, jasa seperti tukang cukur, usaha jahit-menjahit dan sebagainya. Lihat: Tambunan, T. H., 2002, Usaha Kecil dan Menengah di Indonesia: Beberapa Isu Penting, Jakarta: Salemba Empat, hlm. 3 .
Sinkronisasi data rekonsilisasi tahunan kepesertaan BPJS Ketenagakerjaan suatu perusahaan tidak menutup kemungkinan memiliki total rincian iuran tahunan yang memiliki perbedaan antara data perusahaan dengan BPJS Ketenagakerjaan, sehingga menimbulkan selisih pembayaran yang cukup besar dan beresiko tidak hanya terhadap kegiatan pokok perusahaan dalam melakukan kegiatan bisnis 16 tetapi juga mengenai masalah data rekonsiliasi pada tahun-tahun akhir yang tidak juga terselesaikan. Asumsi bahwa keterbatasan pihak perusahaan yang berkompeten dalam menyelesaikannya, atau pihak BPJS Ketenagakerjaan, khususnya bagian data yang sulit untuk melakukan komunikasi kerap terjadi. ${ }^{17}$

\section{b. Faktor-faktor Pendukung}

16 Kegiatan pokok pengusaha adalah menjalankan perusahaan, artinya bukan saja mengurusi pekerjanya, tetapi juga melakukan kegiatan bisnis. Kegiatan bisnis artinya secara terus menerus, terang-terangan untuk memperoleh keuntungan. Selain itu menurut Turisno, bisnis merupakan suatu usaha mempunyai tujuan-tujuan yang salah satu tujuan utamanya adalah untuk memenuhi kebutuhan dan keinginan (need and wants) manusia. Lihat : Bambang Eko Turisno, "Etika Bisnis Dalam Hubungan dengan Transformasi Global Dan Hukum Kontrak Serta Perbuatan Melawan Hukum", Jurnal Masalah-Masalah Hu-kum, Vol. 40 No.3 Juli 2011, Semarang: FH UNDIP, hlm. 291.

${ }^{17} \mathrm{Aku}$ dan BPJS Ketenagakerjaan, http://www.bpjsketenagakerjaan.go.id, diakses Tanggal 17 Juni 2019. 
KA Azizi Noviansyah dan Dimas Agung Ibrahim, Pelaksanaan Prinsip Kepesertaan Bersifat Wajib Pada Sistem Jaminan Sosial Ketenagakerjaan, Halaman 203-222

Faktor-faktor pendukung penerapan prinsip kepesertaan bersiifat wajibpada Sistem Jaminan Sosial Ketenagakerjaan antara lain :

\section{1) Peran Serta Pemerintah}

Peran serta pemerintah dalam mewujudkan Sistem Jaminan Sosial Nasional (SJSN) oleh BPJS Ketenagakerjaan sangat besar. Pemerintah harus mewujudkan Kesejahteraan masyarakat yang berkeadilan sosial melalui pengembangan jaminan sosial ketenagakerjaan yang telah diwujudkan melalui Undang-Undang Nomor 24 Tahun tentang Badan Penyelenggaran Jaminan Sosial (BPJS).

Bapak Achmad Hafiz menyatakan $:^{18}$

"Peran pemerintah yang terpenting adalah hadirnya Undang-Undang Nomor 24 Tahun 2011 tentang Badan Penyelenggaran Jaminan Sosial (BPJS). Undang-Undang inilah yang mengatur BPJS Ketenagakerjaan dengan lima program unggulan. Yaitu, jaminan sosial ketenagakerjaan di bawah naungan BPJS Ketenagakerjaan. Meliputi, Jaminan

\footnotetext{
18 Wawancara dengan Achmad Hafiz selaku Kepala BPJS Ketenagakerjaan Kanwil Sumbagsel, pada Tanggal 10 Mei 2019.
}

Kecelakaan Kerja (JKK), Jaminan Hari Tua (JHT), Jaminan Kematian $(\mathrm{JKm})$, dan Jaminan Pensiun (JP). Kebijakan ini merupakan kewajiban negara untuk menjamin terpenuhi kebutuhan dasar hidup yang layak bagi rakyatnya dan merupakan amanat Undang-Undang Dasar 1945 yang wajib dilaksanakan." 19

\section{2) Ketegasan Penegak Hukum}

Terkait ketegasan penegakan hukum, BPJS Ketenagakerjaan Palembang bakal mempidanakan pengusaha di wilayahnya yang lalai menyetorkan iuran dalam program-program jaminal sosial ketenagakerjaan. Hal tersebut menjadi kewenangan baru dari BPJS Ketenagakeraan sejak tiga aturan diterbitkan pemerintah pusat sejak September $2015^{20}$

\footnotetext{
19 Ditetapkan dalam UUD Negara RI 1945 Pasal 28H ayat (3) bahwa : "Setiap orang berhak atas jaminan sosial yang memungkinkan pengembangan dirinya secara utuh sebagai manusia yang bermanfaat." Pada Pasal 34 ayat (2) berbunyi "Negara mengembangkan sistem jaminan sosial bagi seluruh rakyat dan memberdayakan masyarakat yang lemah dan tidak mampu sesuai dengan martabat kemanusiaaan.”.

${ }^{20}$ Penerbitan tiga aturan baru yang dimaksud itu meliputi PP Nomor 44 Tahun 2015 Tentang Penyelenggaraan Program JKK dan Jaminan Kematian, PP Nomor 45 Tahun 2015 Tentang Pelaksanaan Jaminan Pensiun serta PP Nomor 60
} 
KA Azizi Noviansyah dan Dimas Agung Ibrahim, Pelaksanaan Prinsip Kepesertaan Bersifat Wajib Pada Sistem Jaminan Sosial Ketenagakerjaan, Halaman 203-222

Maka dari itu kebijakan-kebijakan tersebut haruslah terprogram bersama komponen struktur hukum dalam sistem hukum Indonesia dalam lingkup penegakan hukum, yang diatur dalam Undang-Undang No. 8 Tahun 1981 yang meliputi Kepolisian, Kejaksaan, Pengadilan dan Badan Pelaksana Pidana (Lapas). Kewenangan lembaga penegak hukum tersebut dijamin oleh undang-undang, oleh karenanya dalam melaksanakan tugas dan tanggung jawabnya dalam menegakkan kepatuhan terhadap peraturan-peraturan dalam BPJS Ketenagakerjaan, para penegak hukum harus terlepas dari intervensi lembaga eksekutif dan pengaruh eksternal lainnya. ${ }^{21}$

\section{3) Koordinasi Yang Baik Antar} Lembaga dari Tingkat Pusat

\section{Hingga Daerah}

Agar program jaminan sosial ini berjalan optimal, semua pihak harus saling mendukung. Mulai dari pemberi kerja, penerima upah, dan sinergi antara pemerintah pusat hingga pemerintah

Tahun 2015 Tentang Penyelenggaraan Jaminan Hari Tua (JHT).

${ }^{21}$ Sudikno Mertokusumo, Mengenal Hukum, Liberty : Yogyakarta,1986, hlm. 130. daerah. ${ }^{22}$ Pemerintah baik pusat dan daerah yaitu Pemda melalui Kepala Daerah khususnya, ${ }^{23}$ melalui BPJS Ketenagakerjaan bertanggungjawab dalam menjalankan amanah kedaulatan rakyat. ${ }^{24}$ Pengusaha dan pekerja di Indonesia adalah rakyat yang berdaulat.

22 Perlu Kesadaran Perusahaan dan ketegasan Pemerintah, http://riaupos.co, diakses pada 23 Mei 2019, pkl. 13.00 WIB.

${ }^{23}$ Kewajiban Kepala Daerah dan Wakil Kepala Daerah diatur dalam Pasal 27 ayat (1) Undang-Undang Nomor 32 Tahun 2004, sebagai berikut : memegang teguh dan mengamalkan Pancasila, melaksanakan UUD NRI Tahun 1945 serta mempertahankan dan memelihara keutuhan NKRI; meningkatkan kesejahteraan rakyat; memelihara ketentraman dan ketertiban masyarakat; melaksanakan kehidupan demokratis; menaati dan menegakkan seluruh peraturan perundang-undangan; menjaga etika dan norma dalam penyelenggaraan pemerintahan daerah; memajukan dan mengembangkan daya saing daerah; melaksanakan prinsip tata pemerintahan yang bersih dan baik; melaksanakan dan mempertanggungjawabkan pengelolaan keuangan daerah; menjalin hubungan kerja dengan seluruh instansi vertial di daerah dan semua perangkat daerah; dan menyampaikan rencana strategis penyelenggaraan pemerintahan daerah di hadapan Rapat Paripurna DPRD. Lihat : Muhammad Syarif Nuh, "Hakikat Pertanggungjawaban Pemerintah Daerah dalam Penyelengaraan Pemerintahan", Jurnal Masalah-Masalah Hukum Vol.41No.1 Januari2012, Semarang : FH UNDIP, hlm. 52-53.

24 Dalam Teori Kedaulatan Rakyat, pemilik kekuasaan tertinggi yang dalam Negara Indonesia adalah rakyat. Lihat : Jimly Asshiddiqie, Konstitusi dan Konstitusionalisme, Jakarta : Konstitusi Press, 2005, hlm. 58.

Kedaulatan rakyat berarti, rakyatlah yang mempunyai kekuasaan yang tertinggi, rakyatlah yang menentukan corak dan cara pemerintahan, dan rakyatlah yang menentukan tujuan apa yang hendak dicapai. Dalam Pasal 1 ayat (2) Undang-Undang Dasar 1945 setelah amandemen menyatakan bahwa "Kedaulatan berada di tangan rakyat dan dilaksanakan menurut 
KA Azizi Noviansyah dan Dimas Agung Ibrahim, Pelaksanaan Prinsip Kepesertaan Bersifat Wajib Pada Sistem Jaminan Sosial Ketenagakerjaan, Halaman 203-222

\section{4) Sosialisasi Program}

Upaya merangkul media massa tidak hanya terbatas pada mempromosikan pentingnya perusahaan dan para pekerja untuk tergabug dalam BPJS Ketenagakerjaan, tetapi juga dalam rangka penegakan hukum. Kewajiban pengusaha mendaftarkan para pekerjanya adalah suatu kewajiban yang telah ditentukan oleh undang-undang, maka dari itu kelalaian terhadap hal ini akan menimbulkan sanksi bagi perusahaan tersebut, hal inilah yang dinamakan penegakan hukum. Media massa harus secara rutin melakukan sosialisasi sebagai upaya penegakan hukum. Apabila suatu isu hukum berada pada berita utama dan berhari-hari, maka institusi hukum bersama pihak terkait lainnya sperti BPJS Ketenagakerjaan, Pemda, akan bekerja dengan cepat. Namun bila isu tersebut surut dari pemberitaan di media massa, maka surutlah penegakan hukum oleh berbagai institusi hukum dan institusi terkait lainnya. ${ }^{25}$

Undang-Undang Dasar". Lihat : Gusliana. HB, Tinjauan Yuridis terhadap Putusan Mahkamah Konstitusi Nomor 102/PUU-VII/2009 dalam Pemilihan Umum Presiden dan Wakil Presiden Secara Langsung, Jakarta : Raja Grafindo, 2010, hlm. 12.

25 Zulkarnain Ibrahim, Hak Azasi Manusia di Bidang Perburuhan dan Hak Buruh untuk Hidup

\section{5) Sistem Pelayanan dan Kemudahan}

\section{Akses}

Sistem pelayanan dan kemudahan akses merupakan unsur penting dalam pelayanan publik. ${ }^{26}$ Oleh karena itu sistem pelayanan dan kemudahan akses pendaftaran dan klaim di BPJS Ketenagakerjaan Palembang antara lain didukung oleh Penerapan Sistem Pelayanan E-Channel ${ }^{27}$ serta Daya Tanggap dan Komunikasi yang baik.

\section{B. Penutup}

\section{Kesimpulan}

Sejahtera, SimburCahaya, Majalah Ilmiah Vol. XV No.43 Septemberr 2010, Palembang : FH UNSRI, hlm. 2082-2084. Lihat pula : Hikmahanto Juwana, Arah Kebijakan Pembangunan Hukum Di Bidang Perekonomian Dan Investasi, Majalah Hukum Nasional, Vol.1 2007, BPHN Depkumham R.I., hlm. 90-97.

${ }^{26}$ Yanfei Zhou, "A Convergence Analysis on the Efficiency of Public Job Placement Services in Japan", Japan Labor Review, Vol. 5 No. 1, Winter 2008, Hitotsubashi: Hitotsubashi University.

27 Implementasi E-Channel pada hakekatnya merupakan upaya yang menunjang dalam berjalannya program BPJS Ketenagakerjaan. Tujuan sistem E-Channel membantu para pegawai BPJS khususnya custumer service yang berada di cabang Palembang. Beban kerja customer service di BPJS Ketenagakerjaan menjadi berkurang, karena sistem baru E-Channel, merupakan suatu sistem yang cara kerjanya tidak harus datang ke kantor BPJS Ketenagakerjaan langsung yang berada di wilayah Palembang. 
KA Azizi Noviansyah dan Dimas Agung Ibrahim, Pelaksanaan Prinsip Kepesertaan Bersifat Wajib Pada Sistem Jaminan Sosial Ketenagakerjaan, Halaman 203-222

Berdasarkan hasil penelitian dan pembahasan serta analisis yang telah dilakukan, demikian dapat ditarik kesimpulan yang merupakan jawaban atas permasalahan dalam penelitian sebagai berikut :

\section{Penerapan Prinsip Kepesertaan}

\section{Bersifat Wajib Pada Sistem}

Jaminan Sosial Ketenagakerjaan antara lain:

a. Pada pelaksanaannya didasari oleh filosofi kepastian perlindungan bagi manusia untuk kebutuhan-kebutuhan yang hakiki sifatnya melalui asuransi dan diimplementasikan melalui keberadaan BPJS Ketenagakerjaan khususnya sebagai Badan Hukum Publik. Kepastian ini sekaligus mencerminkan nilai keadilan, yang memberi kemanfaatan bagi kelangsungan hidup tenaga kerja dan pemberi kerja dalam koridor perusahaan.

b. Evaluasi penerapan prinsip kepesertaan bersifat wajib yang meliputi Penambahan Perusahaan, Penambahan TK PU (Tenaga Kerja Penerima Upah), Penambahan TK BPU (Tenaga Kerja Bukan Penerima Upah), Perusahaan Aktif, dan Tenaga Kerja Aktif yang belum berjalan dengan baik. Hukum ketenagakerjaan dalam konstitusi hukum merupakan implementasi dari falsafah dasar, yakni Pancasila dan teori dasar (UUD 1945). Nilai dasar tersebut mempunyai aspek kepastian hukum, keadilan, kemanfaatan.

c. Operasional dan Pelayanan BPJS Ketenagakerjaan Kacab Palembang didukung oleh sistem Sumber Daya Manusia yang baik sebanyak 39 personil dan dilaksanakan melalui poin-poin penting seperti akses pada pekerja dimanapun mereka berada, dengan media apapun, kapan pun, serta keunggulan operasional untuk menekan fraud. Kemudahan akses dilaksanakan melalui kemudahan-kemudahan seperti tersedianya Kantor-kantor Pelayanan, Mobil Keliling, Kios-kios Elektronik, Layanan SMS dan Website, aliansi dengan Pemda melalui Desk Service di pemda Tingkat Kabupaten/Kota, serta aliansi Industri Retail seperti Indomaret dan Alfamart.

\section{Faktor Penghambat dan} Pendukung Penerapan Prinsip Kepesertaan Bersiifat Wajibpada Sistem Jaminan Sosial Ketenagakerjaan, yaitu :

\section{Faktor-faktor Penghambat}


KA Azizi Noviansyah dan Dimas Agung Ibrahim, Pelaksanaan Prinsip Kepesertaan Bersifat Wajib Pada Sistem Jaminan Sosial Ketenagakerjaan, Halaman 203-222

a. Tumpang tindih aturan ketenagakerjaan dalam penerapannya acap kali memicu pro kontra dan silang sengketa di bidang ketenagakerjaan.

b. Adanya sanksi administratif kepada pemberi kerja apabila tidak mendaftarkan pekerjanya ke BPJS sesuai Pasal 17 ayat (1) dan (2) huruf c UU BPJS dirasakan cukup berat berat, di sisi lain penyelenggara negara tidak dikenai sanksi administratif tersebut;

c. Lemahnya kesadaran masyarakat dan perusahaan untuk ikut serta menjadi anggota BPJS Ketenagakerjaan;

d. Terbatasnya pertumbuhan kepesertaan pekerja sektor informal yang disebabkan keterbatasan informasi atas manfaat jika terdaftar dalam kepesertaan, serta tingkat kepatuhan pembayaran iuran bulanan, mengingat para pekerja informal sebagian besar bekerja pada sektor perdagangan, ekonomi kreatif, jasa transportasi, pertanian serta beberapa sektor lainnya dengan skala UMKM;

e. Penafsiran aturan yang tidak sama antara badan penyelenggara dan perusahan menyebabkan tidak maksimal berjalannya aturan yang berlaku, yang mengatur hak dan kewajiban tenaga kerja dan pekerja.
Misalnya, terjadinya perbedaan perhitungan nilai iuran yang harus dibayar perusahaan serta miskomunikasi antara perusahaan dengan BPJS Ketenagakerjaan.

\section{Faktor-faktor Pendukung}

a. Peran serta pemerintah dalam menerbitkan Undang-Undang Nomor 24 Tahun 2011 tentang Badan Penyelenggaran Jaminan Sosial (BPJS), untuk menjamin terpenuhi kebutuhan dasar hidup yang layak bagi rakyatnya dan merupakan amanat Undang-Undang Dasar 1945 yang wajib dilaksanakan;

b. Ketegasan penegak hukum bersama Kepolisian, Kejaksaan, dan Kementerian Tenaga Kerja dan Transmigrasi (Kemenakertrans) dalam melakukan penegakan hukum bagi pengusaha yang tidak mendaftarkan pekerjanya dalam program BPJS Ketenagakerjaan dan yang lalai dalam melakukan pembayaran iuran-iuran dalam BPJS Ketenagakerjaan bagi para pekerjanya;

c. Koordinasi yang baik antar lembaga dari tingkat pusat hingga daerah melalui upaya penyempurnaan peraturan perundang-undangan di bidang penyelenggaraan jaminan sosial, pertukaran data dan informasi, 
KA Azizi Noviansyah dan Dimas Agung Ibrahim, Pelaksanaan Prinsip Kepesertaan Bersifat Wajib Pada Sistem Jaminan Sosial Ketenagakerjaan, Halaman 203-222

monitoring dan evaluasi kerjasama, serta peningkatan koordinasi dengan pembentukan tim kerjasama hubungan antar lembaga di tiap wilayah dari tingkat pusat hingga daerah.

d. Sosialisasi Program

BPJS

Ketenagakerjaan dengan

menggandeng kerjasama dengan media massa yang terdiri dari media cetak seperti Sumatra Ekspress dan Tribun Sumsel, juga media elektronik seperti TVRI Sumsel, termasuk juga pemasangan baleho-baleho di lokasi-lokasi jalan protokoler mengenai pentingnya tergabung dalam jaminan sosial ketenagakerjaan.

e. Sistem pelayanan dan kemudahan akses pendaftaran dan klaim melalui sistem pelayanan E-Channel untuk memudahkan pendaftaran, pengajuan klaim, dan pencarian informasi secara online oleh para peserta BPJS Ketenagakerjaan; daya tanggap pelayanan berupa kesediaan penyedia layanan untuk membantu konsumen dan memberikan respon permintaan konsumen dengan segera; serta komunikasi antara pembuat kebijakan dengan pihak pelaksana agar pelayanan dan kemudahan akses dapat berjalan lancar.
Berdasarkan hasil penelitian dan pembahasan serta analisis yang telah dilakukan, demikian dapat diberikan saran atas permasalahan dalam penelitian sebagai berikut :

1. Kepada pemerintah hendaknya mengusulkan revisi UU BPJS kepada DPR mengenai ketentuan sanksi pada pemberi kerja atau perusahaan terhadap kewajiban mendaftar program jaminan sosial tenaga kerja dan sanksi terkait kewajiban pemberi kerja atau perusahaan dalam membayar iuran. Sanksi pidana sebaiknya juga dikenakan bagi pemberi kerja atau perusahaan yang tidak mendaftarkan diri dan pekerjanya pada program jaminan sosial tenaga kerja.

2. Kepada BPJS Ketenagakerjaan Kota Palembang disarankan untuk :

a. meningkatkan sosialisasi kepada masyarakat secara lengkap terutama mengajak peserta yang telah memanfaatkan program BPJS Ketenagakerjaan sebagai role model sehingga dapat meningkatkan pengetahuan masyarakat terkait BPJS Ketenagakerjaan dan diharapkan nantinya akan memudahkan peningkatan cakupan kepesertaan;

\section{Saran}


KA Azizi Noviansyah dan Dimas Agung Ibrahim, Pelaksanaan Prinsip Kepesertaan Bersifat Wajib Pada Sistem Jaminan Sosial Ketenagakerjaan, Halaman 203-222

b. Para petugas diharapkan memberikan pelayanan yang baik kepada para peserta. Adanya pemberian pelayanan yang lebih baik, akan meningkatkan cakupan kepesertaan dan memberikan kepuasan terhadap pelayanan di BPJS Ketenagakerjaan;

c. Menignkatkan kerjasama dalam bentuk Tim Pengawas bersama Dinas Ketenagakerjaan Kabupaten/Kota dan Provinsi, Kepolisian, Perbankan, serta instansi bidang perizinan agar dapat membantu dalam meningkatkan jumlah kepesertaan BPJS Ketenagakerjaan serta mengawasi perusahaan-perusahaan yang tidak mendaftarkan pekerjanya;

d. BPJS Ketenagakerjaan harus lebih aktif mendekatkan diri kepada masyarakat pekerja khususnya pekerja informal, karena jika dilihat dari prinsip kepesertaan bersifat wajib, maka menjadi tanggung jawab bersama untuk meningkatkan jangkauan kepesertaaan BPJS Ketenagakerjaan. Hal ini dapat terwujud salah satunya dengan membuat wadah kelompok-kelompk yang mengakomodir dan mengelola kepesertaan masyarakat pekerja di sektor informal. e. Peran petugas pemeriksa BPJS Ketenagakerjaan saat ini dirasa belum maksimal, hal ini karenakan masih ada kerancuan antara peran petugas pemeriksa di BPJS Ketenagakerjaan dengan pegawai PPNS Disnaker, berkembang isu dengan adanya petugas pemeriksa BPJS Ketenagakerjaan menghapuskan peran Pegawai Pengawas Disnaker. Hal inilah yang menyebabkan banyak terjadi ketidakpatuhan terhadap aturan tentang ketenagakerjaan khususnya terkait kepesertaan BPJS Ketenagakerjaan.

3. Kepada masyarakat disarankan untuk mencermati informasi yang diperoleh saat sosialisasi dari lembaga terkait maupun dari berbagai media, sehingga masyarakat dapat menentukan keputusan yang benar untuk menjadi peserta BPJS Ketenagakerjaan. Selain itu, masyarakat juga diharapkan untuk segera menjadi peserta karena Undang-Undang BPJS mewajibkan seluruh masyarakat Indonesia menjadi peserta BPJS Ketenagakerjaan.

\section{DAFTAR PUSTAKA}

\section{A. Buku}


KA Azizi Noviansyah dan Dimas Agung Ibrahim, Pelaksanaan Prinsip Kepesertaan Bersifat Wajib Pada Sistem Jaminan Sosial Ketenagakerjaan, Halaman 203-222

Abdul Khakim, Pengantar Hukum Ketenagakerjaan Indonesia,

Bandung : PT. Citra Aditya Bakti, 2003.

Abdulkadir Muhammad, 2006, Hukum Asuransi Indonesia, Bandung : PT. Citra Aditya Bakti, 2006.

Adrian Sutedi, Hukum Perburuhan, Jakarta : Sinar Grafika, 2009.

Agusmidah, Dinamika dan Kajian Teori

Hukum Ketenagakerjaan Indonesia,

Bogor: Ghalia Indonesia, 2010.

Asri Wijayanti, Hukum

Ketenagakerjaan, Jakarta: Sinar Grafika, 2009.

Basrowi dan Suwandi, Penelitian Kualitatif, Jakarta: PT. Rineka Cipta, 2008.

Ghazmahadi, Era Baru Jaminan Sosial

Nasional : Menciptakan Rasa Aman dalam Bekerja dan Usia Tua, Jakarta: BPJS Ketenagakerjaan, 2012.

Husni Lalu, Pengantar Hukum Ketenagakerjaan Indonesia, Jakarta:

PT. Raja Grafindo Persada, 2007. Johnny Ibrahim, Teori \& Metodologi Penelitian Hukum Normatif, cet III, Malang: Bayumedia Publishing, 2005.

Mochtar Kusumaatmadja, Pengantar

Ilmu Hukum, Suatu Pengenalan
Perrtama Ruang Lingkup Berlakunya Ilmu Hukum, Bandung : Alumni, 2000.

Ratminto, Manajemen Pelayanan, Yogyakarta: Pustaka Belajar, 2011. Rusli Hardijan, Hukum Ketenagakerjaan, Bogor: Ghalia Indonesia, 2011.

Sentosa Sembiring, Himpunan Undang-Undang Lengkap Tentang Asuransi Jaminan Sosial, Bandung: Nuansa Aulia, 2006.

Tim Peneliti PSIK, Negara Kesejahteraan dan Globalisasi, Pengembangan Kebijakan dan Perbandingan Pengalaman, Jakarta: Univ. Paramadina, 2008.

Wirdjono Prodjodikoro, Hukum Asuransi di Indonesia, Jakarta: Rineka Cipta, 2010.

Zainal Asikin, Dasar-dasar Hukum Perburuhan, Jakarta: PT. Raja Grafindo Persada, 1993.

\section{B. Jurnal dan Sumber Lain}

Muhammad Syaifuddin, "Nasionalisasi Perusahaan Modalasing Ide Normatif Pengaturan Hukumnya Dalam UU NO.25 Tahun 2007 Dan Relevansinya Dengan Konsep Negara Hukum Kesejahteraan ancasila Dalam UUD 1945", Jurnal Simbur Cahaya,Vol. XVII 
KA Azizi Noviansyah dan Dimas Agung Ibrahim, Pelaksanaan Prinsip Kepesertaan Bersifat Wajib Pada Sistem Jaminan Sosial Ketenagakerjaan, Halaman 203-222

No.47 Januari 2012, Palembang: FH UNSRI.

Sri Mulyani, Pengembangan Hak Kekayaan Intelektual sebagai Colateral (Agunan) untuk Mendapatkan Kredit Perbankan di Indonesia, Jurnal Dinamika Hukum, Vol. 12 No. 3 2012, Purwokerto: Fakultas Hukum Unsoed.

Zen Zanibar, Perizinan dan Ketenagakerjaan (Fenomena Otonomi Daerah Merespons Pasar Global), Jurnal Simbur Cahaya,Vol.XVIINo. 4, 8 Mei 2012, Palembang: FH UNSRI.

Zulkarnain Ibrahim, Pengaturan dan Penegakan Hukum Pengupahan dalam Sistem Hukum Ketenagakerjaan, Jurnal Hukum Ius Quia Iustum, 2015, 22 (4). pp. 652-673. ISSN 0854-8498.

Zulkarnain Ibrahim, Hak Azasi Manusia di Bidang Perburuhan dan Hak Buruh untuk Hidup Sejahtera, Simbur Cahaya, Majalah Ilmiah Vol. XV No.43 September 2010, Palembang: FH UNSRI.

Zulkarnain Ibrahim, Pengaturan Hukum Pengupahan Dalam Upaya Mewujudkan Kesejahteraan Sosial Yang Berkeadilan Substantif, Disertasi pada Program Studi Doktor
Ilmu Hukum Fakultas Hukum Universitas Sriwijaya Palembang 2014.

Visi dan Misi BPJS Ketenagakerjaan, http://www.bpjsketenagakerjaan.go.id Presiden Jokowi : Setiap Pekerja Kini Wajib Jadi Peserta BPJS Ketenagakerjaan, http://setkab.go.id. Kepesertaan Wajib BPJS Bukan Domain Swasta,

http://www.hukumonline.com.

Zulkarnain Ibrahim, Buruh Kontrak : Dilema di Negara Kesejahteraan Studi terhadap PKWTT dan Outsourching, http://www.fh.unsri.ac.id.

Zulkarnain Ibrahim, Eksistensi Hukum Pengupahan Yang Layak Berdasarkan Keadilan Substantif, $\quad$ http:// dinamikahukum.fh.unsoed.ac.id.

\section{Peraturan Perundang-undangan}

Undang-Undang Dasar RI Tahun 1945.

Kitab Undang-Undang Hukum Pidana (KUHP).

Undang-Undang RI Nomor 13 Tahun 2003 Tentang Ketenagakerjaan.

Undang-Undang RI Nomor 40 Tahun 2004 Tentang Sistem Jaminan Sosial Nasional (SJSN). 
KA Azizi Noviansyah dan Dimas Agung Ibrahim, Pelaksanaan Prinsip Kepesertaan Bersifat Wajib Pada Sistem Jaminan Sosial Ketenagakerjaan, Halaman 203-222

Undang-Undang RI Nomor 20 Tahun 2008 Tentang Usaha Mikro, Kecil, dan Menengah (UMKM).

Undang-Undang RI Nomor 24 Tahun 2011 Tentang Badan Penyelenggara Jaminan Sosial (BPJS).

Undang-Undang RI Nomor 40 Tahun $2014 \quad$ Tentang Usaha

Perasuransian.

Peraturan Pemerintah RI Nomor 86

Tahun 2013 Tentang Tata Cara

Pengenaan Sanksi Administratif

Kepada Pemberi Kerja Selain

Penyelenggara dan Setiap Orang,

Selain Pemberi Kerja, Pekerja, dan

Penerima Bantuan Iuran Dalam

Penyelenggaraan Jaminan Sosial.

Keputusan Menteri Pekerja RI No.

KEP-150/MEN/2000 Tentang

Penyelesaian Pemutusan Hubungan

Kerja dan Penetapan Uang Pesangon

Uang Penghargaan Masa Kerja dan

Ganti Rugi di Perusahaan. 